\title{
Nataliia Lobachova,
}

Chair of the Russian Language, Theory and History of Literature

Crimean University for the Humanities

\section{FORMATION OF LEARNERS' (SCHOOLCHILDREN) SOCIO-CULTURAL COMPETENCE IN MULTILINGUAL AND MULTICULTURAL ENVIRONMENT}

\begin{abstract}
The article is devoted to the study of peculiarities of multilingual education in schools under conditions of multicultural region. There are considered such issues as aspects of intercultural communication, formation of socio-cultural competence of learners (schoolchildren).
\end{abstract}

Key words: multilingualism, multicultural, socio-cultural, intercultural communication, socio-cultural competence.

Socio-cultural situation in Ukraine and, in the Autonomous Republic of Crimea in particular, in late $20^{\text {th }}-$ early $21^{\text {st }}$ century is characterized by activization of national self-conscience and cultural identity of different ethnical and social groups, that guarantees preservation of historical memory, development of the "small motherland" feeling, languages, traditions and beliefs revival, i.e. unique and distinctive culture of ethnic minorities.

According to the 2001 census Crimea is the home to 125 ethnic groups among which there are representatives of Indo-European,
Altai, Urals, Afro-Asiatic, Kartvelian, North-Caucasian language families. Taking into account the fact that not less than 5\% of representatives of each ethnos referred to the language of their nationality as their native language, the school faces an issue of providing educational services under conditions of multicultural region.

The purpose of the article: to study peculiar properties of schoolchildren socio-cultural competence formation in multilingual and multicultural environment, namely, in the Autonomous Republic of Crimea.

The issues of multilingual education are 
considered in the works by Ye.M. Vereschagin, G.A. Zograf, A.G. Shirin, N.Ye. Bulankina, A.T. Kulsariyeva, M.G. Haskelberg, L.P. Khabarova and others. Issues of intercultural communication are revealed in the researches by S.G. TerMinasova, A.D. Shveitser, L.B. Nikolsky and others.

Multilingualism (in Russian also: полилингвизм, многоязычие) is the use of several languages within the boundaries of a certain social entity (i.e. a state); use by a person (group of people) of several languages each of which is chosen due to the particular communicative situation $[6$, p.303].

Investigating phenomenon of multilingualism we cannot ignore the actual educational system in Ukraine since learning state, native and foreign languages is a component of basic school program. Multilingualism sets the task for an educational system to prepare the new generation to effective communication under conditions of multinational and multicultural environment.

The Autonomous Republic of Crimea, as mentioned above, is a multicultural region. It is beyond doubt that multilingualism is a means of person socialization, it develops the basis for tolerant relationships between peoples living in Crimea.
According to A.G. Shirin, the social nature of modern multilingual education lies not only in formation of linguistic, but wider socio-cultural and intercultural competences and authentic contextual interpretation of meanings in communication of different cultures representatives [5].

The level of education multiculturalism will depend on the way certain material on the culture of people of the target foreign language is presented and the way it's interconnected with material about other cultures.

The main task of education and instruction at the modern stage of society development is to form positive attitude to universal and national values.

Through learning a foreign language schoolchildren come in touch with the people's culture - certain language-carriers. Pursuing the goal of motivating schoolchildren to learn several languages a teacher should think carefully about directions, types, forms and methods of linguistic and culture-oriented material delivery.

Specifics of multicultural education at schools are connected with various psychological and pedagogical, linguistic and didactic, cultural, social and communicative, ethic and other factors. Pursuing the goal of this article we will focus on consideration 
of implementation of socio-cultural aspect in school education.

Socio-cultural aspect presupposes possession of knowledge about national and cultural features of the country of the taught language, and culture of verbal behavior. It includes knowledge in linguistic and area studies (background characters, trivia of the country of the target language, verbal and non-verbal behavior in situations of oral communication, non-equivalent lexical units); area studies knowledge (nature and climate conditions, societal, political and economical peculiarities, major stages of historical and cultural development of the country of the target language); cultural knowledge (traditions and customs, routine life, peculiarities of national character and psychology of the country of the target language) [3].

With regard to the above we can outline the following socio-cultural vectors contributing to formation of linguistic, socio- and intercultural competences:

- Creation of stimulating communication environment.

- Linguistic and area studies activities.

- Educational and research project activity.
- Purposeful use of cinema discourse.

It is suggested that the above-listed components should be implemented not only in the language and literature classes, but in other classes of the humanities cycle, as well as in after-classes activities.

Creation of stimulating communication environment presupposes purposeful teacher's efforts enabling schoolchildren to come in touch with the culture of the people/ nation, form steady interest in various representations of national culture and the need in getting acquainted with culture-oriented texts belonging to different functional styles etc.

There are the following ways of introducing culture-oriented information into the educational material: selection by a teacher of culture-oriented texts for further complex linguistic, lingua-stylistic and linguacultural analysis; organization of excursions/ virtual tours to museums, exhibitions other places connected with the national culture of the target language followed by a discussion in a target language, writing essays etc.

Leading activities: role plays as a sample of social context; creation of communication provoking situations.

Of utmost efficiency, according to T.V. Nayorova, S.A. Popova and T.N. Velichko, is the use of local toponymy in the process 
of linguistic and area studies activity. In multicultural region lingua- and arearelated activity becomes of special importance: toponymic vocabulary reflects the crucial stages in the history of material and spiritual culture of people and at the same time it traces linguistic regularities making this linguistic layer interesting from the point of view of its historical and geographical contents and linguistic source [4, p. 24].

According to T.N. Velichko the use of toponymic material in the language teaching process facilitates: nurture love for and formation of interest towards the "small" motherland; enrichment and activization of learners' vocabulary and, finally, it forms socio-cultural and intercultural competences, provides an opportunity to implement an actual idea of introducing regional component in the system of linguistic education [2, p. 11].

There are the following ways of introducing culture-oriented information within the framework of language and area studies activities into the educational material:

1. The use of rich information environment: "Toponymy of the home city/ homeland", "Origin of proper names of geographic entity", "Main street of the home city", "History of the home city in the names of outstanding people", "Toponyms in the works of art" etc.

Types of activities: learners' individual work in making presentations on the given topics, solving/ composing crosswords, writing essays in the wake of excursions "My street", "Streets named in honour of heroes", carrying out discussions, quizzes, didactic games etc.

2. Visits to local lore museums. Types of activities: organization of excursion, virtual tour, meetings with the staff of local lore museums, historians, philologists etc., discussions in the wake of excursions, composing short stories about the homeland by senior learners for junior ones, carrying out excursions for them. Information can be provided partially in the native language, and partially in the foreign target language.

3. Work with texts containing information about the origin of geographic entities names in a certain area, proper names.

Types of activities: analysis of toponyms applying elements of lexico-semantic and etymological word analysis; didactic games, short essays.

Educational and research project activity presupposes the use of project method in educational process oriented at creative self-realization of learners' personality, development of their intellectual ca- 
pacities, the power of will and creativity in the process of creating a new product under teacher's supervision.

Of great importance for successful organization of project activity is preparation of a project task by a teacher, i.e. an object of project activity, fulfillment of which demands the search of arguments, integration of knowledge and skills. For example, tasks in the culture of speech should stimulate learners to carry out comparative analysis of cultures, namely, of native and nonnative target language, establish connection between language, thinking and culture, study cultural artifacts.

These tasks contribute to development of a human being as personality, as a subject of cultures; improve intercultural and sociocultural competences in the process of language learning.

Purposeful use of cinema discourse presupposes creation by a teacher of a catalogue of films containing socio-cultural information and recommended for the learners' individual watching; watching fragments of films followed by discussion. It should be mentioned that depending on the lesson's goal and type a film fragment can be presented in native as well as non-native target language.

Leading types of activities: discussion, es- say, written review.

Sharing the point of view of N.Ye. Bulankina, we suppose that the precondition of effective cultural self-determination is language and speech activism in interaction with representatives of other cultural communities by means of these cultures' languages - i.e. universal form of reality comprehension that organizes emerging or already existing representations, perceptions, concepts, images and other relevant semantic structures [1].

Based on the above we can conclude:

1. A human being (man) exists not only in multicultural but also in multilingual societal environment since it is the language that reflects national / global values of spiritual culture.

2. Multilingualism as a leading demand of modern socio-cultural situation promotes understanding and effective cooperation between members of different ethnic groups / nations / nationalities, enrichment of native languages, enhancing the overall culture of a man as a social entity.

3. Teacher needs to cultivate respect for diverse cultural differences, which lies in level of understanding and acceptance of other cultures through the study of cultural differences; and in the formation of learners' appreciation of cultural differences and 
their approval through participation in various cultural practices that involve proactive position of intercultural communication participants.

Thus, using socio-cultural aspect in teaching process in a multicultural region a teacher needs to foster learners' linguistic competence and intercultural skills, familiarize learners with the ways of activity in a multicultural society and help gain experience of effective cross-cultural interaction. 


\section{References}

Bulankina N. Ye. Language. Culture. Education. Experience of philosophical comprehension/ Bulankina N. Ye. // Siberian teacher. - 2010. - №6(73). - p. 12- 18.

Linguistics. New Collegiate Dictionary / [V.N. Yartseva]. - $2^{\text {nd }}$ edition. - Moscow: Great Russian Encyclopedia, 2000. - 688 p.

Mayorova T.M. Onomastics in linguistics and local history studies / T.M. Mayorova // Russian language in school. - 2000. - №3. - p. 23 -28.

Shirin A.G. Pedagogical aspects of bilingualism: development of new scientific school / Shirin A.G. // [on-line resourse]: http://edu.novgorod.ru

Velichko T.N. Formation of learners' socio-cultural competence at the classes of the Russian language / Velichko T.N. // Russian language in school. - 2011. - №4. - p. 5 -11.

Yegoshina T.S. Socio-cultural aspect in foreign language learning / Yegoshina T.S. // [on-line resource]: http://festival.1september.ru/articles/529327/ 